\title{
ANALISIS KESESUAIAN PERAIRAN UNTUK BUDIDAYA IKAN KERAPU BEBEK (Cromileptes altivelis) DI PERAIRAN PULAU TEGAL TELUK LAMPUNG
}

\author{
Desti Rizki Anggraini *1, Abdullah Aman Damai, dan Qadar Hasani*2 \\ DOI: http://dx.doi.org/10.23960/jrtbp.v6i2.p719-728
}

\begin{abstract}
Tegal Island is part of Lampung Bay which has potential to be the location of aquaculture. One of kind fish that can be cultivated in these area is the humpback grouper (Cromileptes altivelis). Humpback grouper is the most popular fish species in local and foreign markets that have the highest selling price. The purpose of this study were to know the physical and chemical parameters in Tegal Island waters, to know the suitability of the waters for the humpback grouper cultivation in the waters of Tegal Island. The research was conducted in May 2017. The sampling location was 4 stations. The range of water quality values in Tegal island were water depth (15-25 m), dissolved oxygen $(7-8 \mathrm{mg} / \mathrm{l})$, brightness $(5-10 \mathrm{~m})$, salinity (30-34 ppt), temperature $\left(28-32^{\circ} \mathrm{C}\right)$, current velocity $(20-50 \mathrm{~m} / \mathrm{s}), \mathrm{pH}(7,7-$ $8,0)$, nitrate $(0,9-3,2 \mathrm{mg} / \mathrm{l})$ and phosphate $(0,2-0,5 \mathrm{mg} / \mathrm{l})$. The results showed that the waters of Tegal Island had appropriate water suitability level (St 3), corresponding marginally (St 1 and St 2) and unsuited (St 4) for the cultivation of humpback grouper.
\end{abstract}

Keywords: Tegal Island, humpback grouper, waters evaluation

\section{Pendahuluan}

Wilayah pesisir memiliki potensi danperan strategis sebagaisalah satu penunjangkegiatan wilayah daratan yang ada disekelilingnya termasuk kegiatan budidaya.Wilayah pesisir Teluk Lampung memiliki keragaman hayati dan potensi sumber daya perikanan dan kelautan yang besar sebagai pendukung kegiatan perekonomian di Provinsi Lampung terutama bagi masyarakat di wilayah pesisir.Salah satu lokasi yang dapat digunakan dalam kegiatan tersebut yaitu Perairan Pulau Tegal.

Secara administratif, Pulau Tegal terletak di Kecamatan Teluk Pandan, Kabupaten Pesawaran, Provinsi Lampung dengan luas lebih dari 98 ha.Pulau Tegal memiliki topografi berupa pantai pasir putih yang landai (Sebelah Barat, Selatan, Timur, dan Utara), pantai berbatu (sebelah Timur Laut, Tenggara, Barat Daya, dan Barat Laut) (Departemen Kelautan dan Perikanan, 2002).Wilayah daratannya berupa dataran (dekat pantai) hingga berupa lerengan bukit

\footnotetext{
${ }^{1}$ E-mail: adestizki@gmail.com

${ }^{2}$ Jurusan Perikanan dan kelautan, Fakultas Pertanian, Universitas Lampung Jl. Prof. S. Brodjonegoro No.1 Gedong Meneng Bandar Lampung 35145
} 
(biasanya untuk bercocok tanam bagi penduduk). Pada umumnya masyarakat di Pulau Tegal memiliki KJA untuk budidaya.

Ikan kerapu bebek (Cromileptes altivelis) merupakan salah satu jenis ikan yang paling populer di pasar lokal maupun manca negara.Ikan kerapu tergolong dalam famili Serranidae, tubuhnya tertutup oleh sisik-sisik kecil. Menurut Nontji (2005) nama kerapu biasanya digunakan untuk empat genus anggota famili Serranidae yaitu Epinephelus, Variola, Plectropomus dan Cromileptes. Salah satu ikan kerapu yang diminati adalah ikan kerapu bebek (Cromileptes altivelis).Ikan kerapu bebek merupakan jenis ikan yang memiliki harga jual paling tinggi diantara jenis ikan kerapu lainnya (Aslianti et al., 2003).

Terdapat beberapa faktor pendukung untuk keberhasilan budidaya ikan kerapu bebek. Salah satu faktor yang mendukung keberhasilan tersebut adalah kualitas air. Semakin buruk keadaan suatu perairan maka semakin kecil harapan biota laut dapat hidup sesuai habitat aslinya. Oleh sebab itu, perlunya kajian tentang kualitas air sebagai penentu lokasi budidaya khususnya ikan kerapu bebek.

\section{Metode}

Penelitian ini dilaksanakan pada bulan Mei 2017 dengan lokasi penelitian terletak di Perairan Pulau Tegal, Kecamatan Teluk Pandan, Kabupaten Pesawaran, Provinsi Lampung. Analisis sampel penelitian ini dilakukan di Laboratorium Balai Besar Perikanan Budidaya Lampung (BBPBL).

Alat yang digunakan pada penelitian yaitu termometer, $\mathrm{pH}$ paper, secchi disk, pemberat manual, hand refractometer, DO meter, spektrofotometer, pengukur arus manual, stopwatch, dan GPS.

Data yang digunakan bersumber dari data primer meliputi kualitas perairan di Pulau Tegal sedangkan data sekunder meliputi peta lokasi pengambilan sampel. Lokasi pengambilan sampel sebanyak 4 stasiun yaitu di dekat $\mathrm{KJA}\left(5^{\circ} 33^{\prime}\right.$ $36,49^{\prime \prime}$ LS dan $105^{\circ} 16^{\prime} 22,04^{\prime \prime}$ BT), di daerah terumbu karang ( $5^{\circ} 33^{\prime}$ 40,75" LS dan $105^{\circ} 16^{\prime}$ 31,16" BT), di daerah dekat pemukiman $\left(5^{\circ} 33^{\prime}\right.$ 30,33" LS dan $105^{\circ} 16^{\prime} 33,44^{\prime \prime}$ BT) dan diantara Pulau Tegal dan Pantai Sari Ringgung ( $5^{\circ} 33^{\prime} 24,95^{\prime \prime}$ LS dan $105^{\circ} 16^{\prime} 20,53^{\prime \prime}$ BT).

Parameter yang diamati adalah kedalaman perairan, kecerahan perairan, suhu dan kecepatan arus, oksigen terlarut (DO), $\mathrm{pH}$, salinitas, Nitrat $\left(\mathrm{NO}_{3}-\mathrm{N}\right)$, dan Fosfat $\left(\mathrm{PO}_{4} \mathrm{P}^{-}\right)$.

Tabel penilaian untuk lokasi budidaya ikan kerapu bebek di Pulau Tegal dapat dilihat pada Tabel 1.

Tabel 1. Penilaian parameter kualitas air untuk analisa kesesuaian lahan

\begin{tabular}{lcccc}
\hline Parameter & Kisaran & $\begin{array}{c}\text { Angka } \\
\text { Penilaian }(\mathbf{A})\end{array}$ & Bobot $(\mathbf{B})$ & $(\mathbf{A}) \mathbf{x}(\mathbf{B})$ \\
\hline \multirow{2}{*}{ Kedalaman } & $15-25 \mathrm{~m}$ & 5 & 3 & 15 \\
& $4-14 \mathrm{~m}$ dan $14-24 \mathrm{~m}$ & 3 & &
\end{tabular}




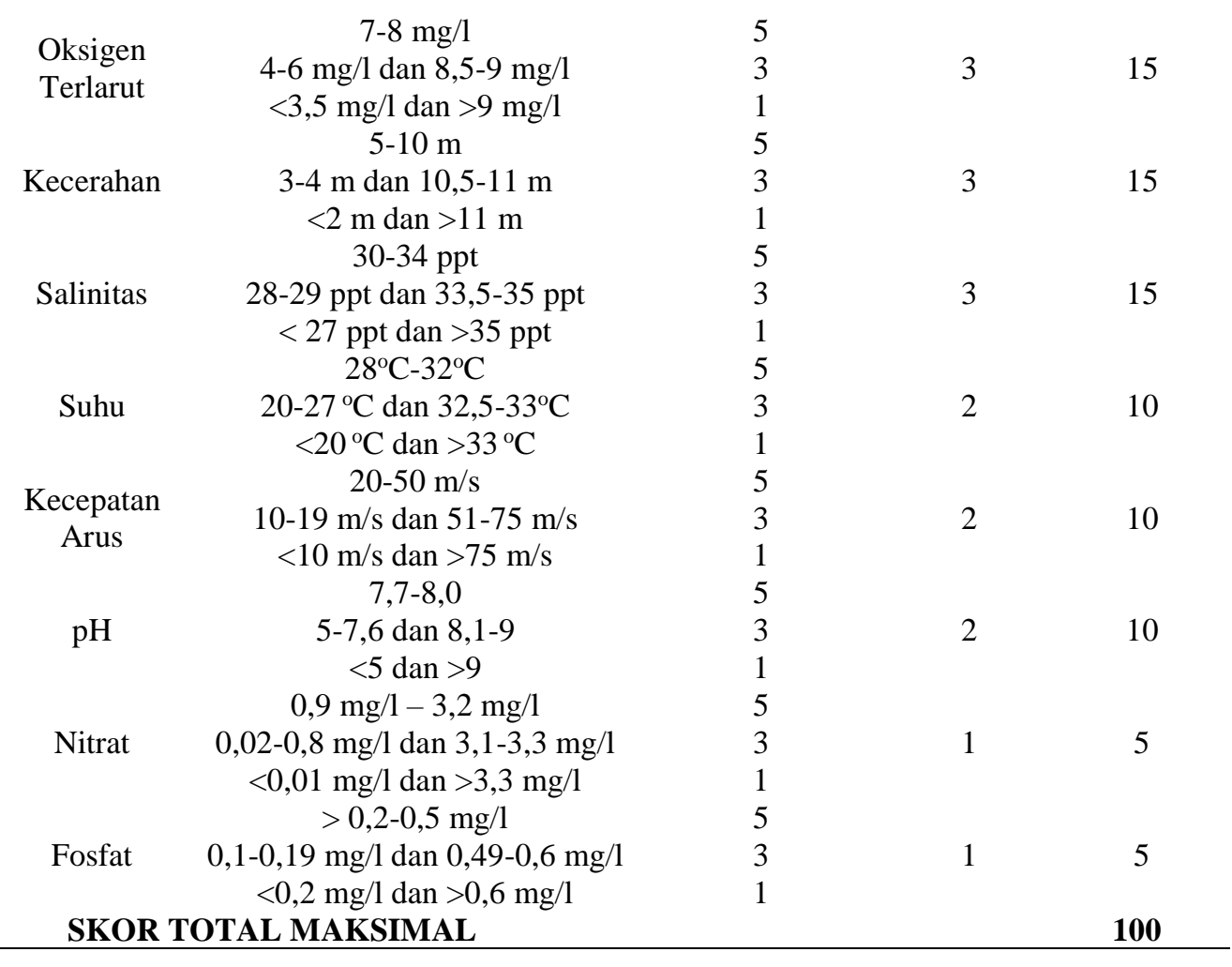

Skor total dari hasil perkalian nilai parameter dengan bobotnya tersebut selanjutnya dipakai untuk menentukan kelas kesesuaian lahan budidaya ikan kerapu bebek berdasarkan karakteristik kualitas perairan dan dapat dihitung dengan perhitungan (Departemen Kelautan dan Perikanan, 2002) :

$$
\text { Skor total }=\frac{\text { Skor total }}{\text { Skor total } \max } \times 100 \%
$$

Evaluasi Kesesuaian digolongkan ke dalam beberapa kelas yaitu :

- Kelas S1 : sangat sesuai (hightly suitable) dengan nilai $85-100 \%$

- Kelas S2 : cukup sesuai (Moderately Suitable) dengan nilai $75-84 \%$

- Kelas S3 : sesuai marginal (marginally suitable) dengan nilai $65-74 \%$
- Kelas N : tidak sesuai (not suitable) dengan nilai $<65 \%$.

\section{Hasil dan Pembahasan}

Keadaan Lokasi Penelitian

Pulau Tegal memiliki luas \pm 98 hadengan jumlah penghuni sekitar 20 kepala keluarga.Secara administratif, pulau ini masuk dalam wilayah Kabupaten Pesawaran, Provinsi Lampung. Pulau Tegal terletak pada koordinat $05^{\circ} 34^{\prime} 05^{\prime}$, LS dan $105^{\circ} 16^{\prime} 31^{\prime \prime}$ BT. Topografi yang dimiliki berupa pantai pasir putih yang landai (Sebelah Barat, Selatan, Timur, dan Utara), pantai berbatu (sebelah Timur Laut, Tenggara, Barat Daya, dan Barat Laut). Wilayah daratannya berupa dataran (dekat pantai) hingga berupa lerengan bukit (biasanya untuk bercocok tanam bagi penduduk), (Departemen Kelautan dan Perikanan, 2002). 
Untuk menuju Pulau Tegal dapat ditempuh dari berbagai tempat di sekitar pesisir Kabupaten Pesawaran, seperti dari Pantai Mutun (1,5 - 2 jam), BBL Hanura $(1-1,5$ jam $)$ atau dari Pantai Ringgung (20 - 40 menit).

\section{Kualitas Air}

Hasil pengukuran kualitas air untuk lokasi budidaya ikan kerapu bebek di Pulau Tegal dapat dilihat pada Tabel 2.

\begin{tabular}{lccc}
\hline Oksigen & $7,30-9,54$ & 7,94 & In situ \\
Terlarut (mg/l) & $7,69-76,9$ & 39,46 & In situ \\
Kecerahan (m) & 32 & 32 & In situ \\
Salinitas (ppt) & 30 & 30 & In situ \\
$\begin{array}{l}\text { Suhu }\left({ }^{\circ} \mathrm{C}\right) \\
\text { Kecepatan Arus } \\
(\mathrm{cm} / \text { detik) }\end{array}$ & $0,04-0,11$ & 0,075 & In situ \\
$\mathrm{pH}$ & 6 & 6 & $\begin{array}{l}\text { In situ } \\
\text { Lab. }\end{array}$ \\
Nitrat (mg/l) & $0,828-0,999$ & 0,902 & BBPBL \\
Fosfat $(\mathrm{mg} / \mathrm{l})$ & $0,374-0,522$ & 0,420 & Lab. \\
& & & \\
\hline
\end{tabular}

\section{Kedalaman Perairan Pulau Tegal}

Hasil pengukuran kedalaman

Tabel 2. Data pengukuran kualitas air di Perairan Pulau Tegal

\begin{tabular}{|c|c|c|c|c|}
\hline Variabel & Kisaran & Rerata & Ket & dilihat nada Gambar \\
\hline Kedalaman (m) & $13-27$ & 22,16 & In situ & \\
\hline
\end{tabular}

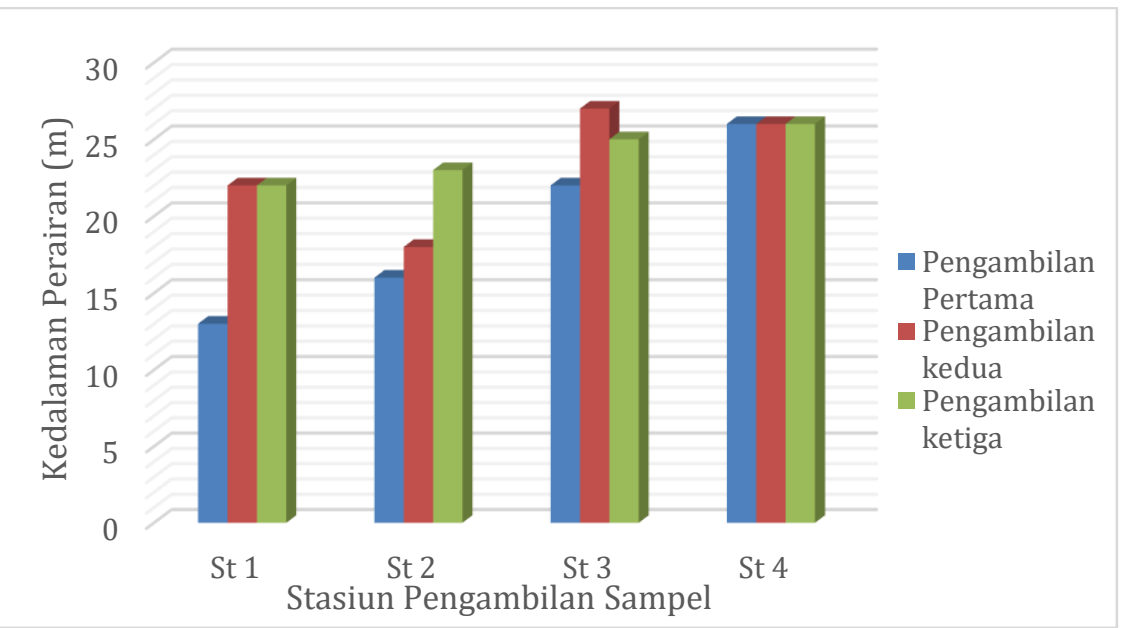

Gambar 1. Kedalaman di perairan Pulau Tegal

Berdasarkan Gambar 1 diketahui nilai kedalaman pada perairan Pulau Tegal berkisar antara 13-27 m untuk seluruh stasiun dengan nilai rata-rata 22,16 m. Hasil ini dianggap cukup baik untuk mendukung kegiatan budidaya ikan kerapu bebek karena menurut Kordi dan Andi (2005), kedalaman optimal perairan yang dapat digunakan untuk budidaya ikan kerapu bebek berada pada kisaran 15 - 25 m (Tabel 1).

Oksigen Terlarut Perairan Pulau Tegal

Hasil pengukuran kandungan oksigen untuk lokasi budidaya ikan kerapu bebek di Pulau Tegal dapat dilihat pada Gambar 2. 


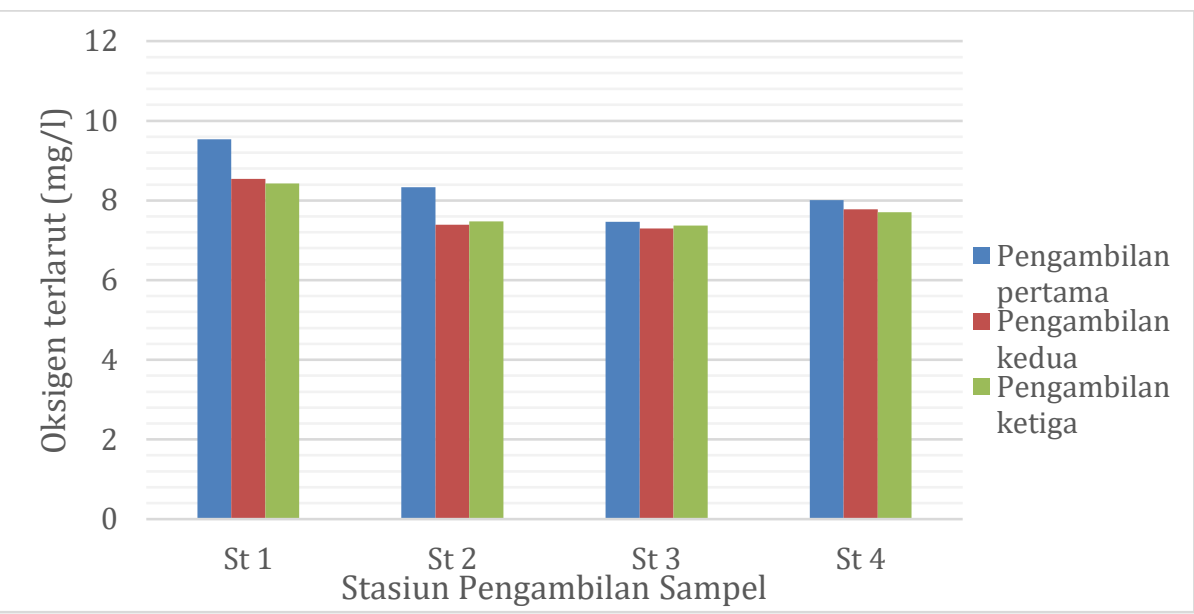

Gambar 2. Kandungan oksigen terlarut di Perairan Pulau Tegal

Berdasarkan Gambar 2 diketahui bahwa hasil dari kandungan oksigen terlarut di perairan Pulau Tegal berkisar antara $7,30-9,54 \mathrm{mg} / \mathrm{l}$ dimana dari hasil pengambilan sampel ini dapat di rata-ratakan dengan jumlah $7,94 \mathrm{mg} / \mathrm{l}$. Hal ini berarti nilai oksigen terlarut pada perairan Pulau Tegal sangat baik untuk mendukung keadaan budidaya ikan kerapu bebek karena ikan kerapu dapat hidup layak dengan konsentrasi oksigen terlarut lebih dari $5 \mathrm{mg} / \mathrm{l}$ (Evalawati et al., 2001).

\section{Suhu Perairan Pulau Tegal}

Suhu perairan Pulau Tegal memiliki hasil yang sama di setiap lokasi yaitu sebesar $30^{\circ} \mathrm{C}$. Suhu yang baik untuk budidaya ikan kerapu bebek ini berkisar antara $28-32{ }^{\circ} \mathrm{C}$ (Tabel 1). Nilai dari pengukuran suhu ini juga tergantung pada waktu pengambilan sampel. Pada siang hari intesitas cahaya matahari yang masuk ke dalam suatu perairan lebih banyak dibandingkan pada pagi dan malam hari.Suhu perairan di lokasi penelitian dianggap masih baik untuk pertumbuhan ikan kerapu bebek sesuai dengan Tiskiantoro (2006) yang menyebutkan bahwa suhu optimal untuk budi daya ikan kerapu bebek $C$. altivelis adalah $27-32{ }^{\circ} \mathrm{C}$.

\section{Salinitas Perairan Pulau Tegal}

Salinitas yang didapatkan di perairan ini adalah 32 ppt. Masingmasing stasiun mendapatkan hasil yang sama. Menurut Kordi dan Ghufran (2004) pada budidaya ikan kerapu bebek salinitas yang baik adalah 33 - 35 ppt. Sedangkan dijelaskan pada Tabel 1, bahwa salinitas 32 ppt ini juga termasuk salinitas yang baik untuk kegiatan budidaya ikan kerapu bebek.Salinitas untuk budidaya ikan kerapu yang baik adalah berkisar 30 - 34 ppt (Paruntu, 2015).

\section{Kecerahan Perairan Pulau Tegal}

Nilai kecerahan untuk lokasi budidaya ikan kerapu bebek di Pulau Tegal dapat dilihat pada Gambar 3. 


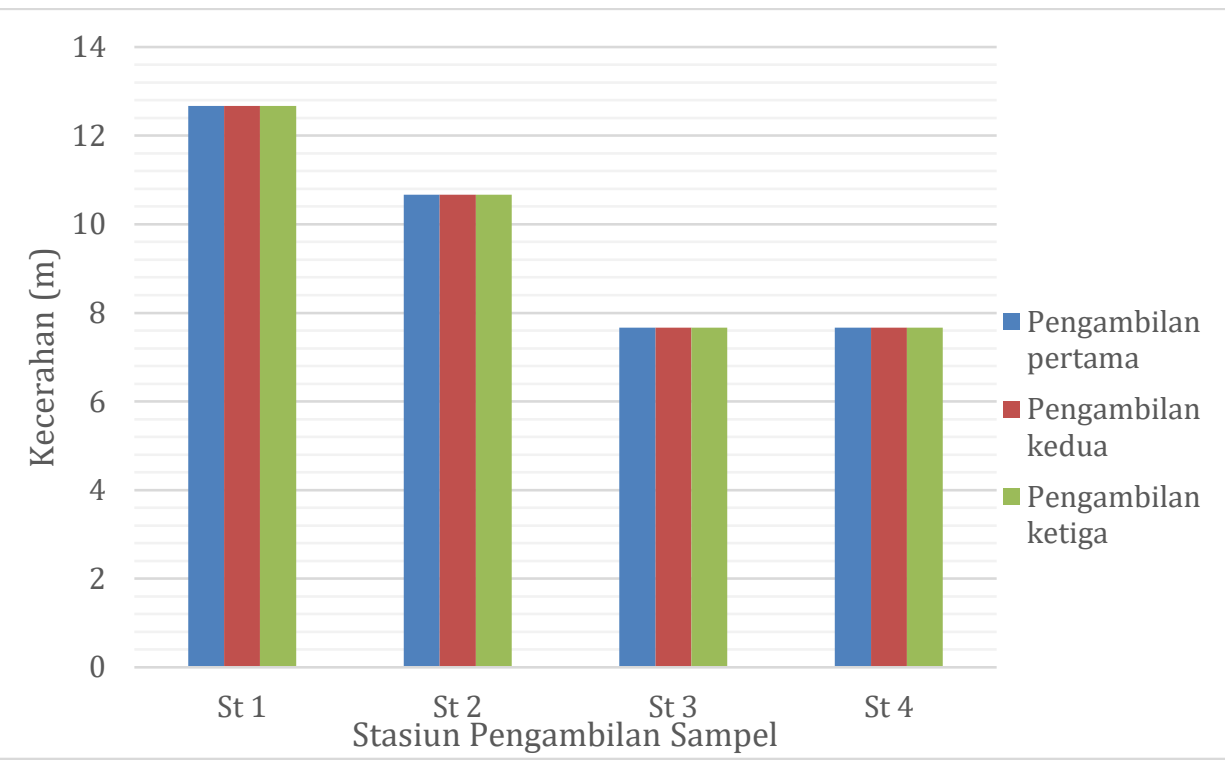

Gambar 3. Kecerahan di Perairan Pulau Tegal

Berdasarkan Gambar 3 diketahui kecerahan di perairan Pulau Tegal memiliki hasil terendah pada 7,67 dan hasil tertinggi 12,67. Kecerahan pada perairan ini dianggap sedang untuk budidaya ikan kerapu bebek (BBL Lampung, 2001) (Tabel 1). Hal ini disebabkan karena semakin keruh suatu perairan maka semakin sedikit pula cahaya dapat masuk dan tingkat kecerahan juga menjadi rendah (Mujito et al., 1997).

\section{Kecepatan Arus Perairan Pulau} Tegal

Hasil pengukuran kecepatan arus untuk lokasi budidaya ikan kerapu bebek di Pulau Tegal dapat dilihat pada Gambar 4.

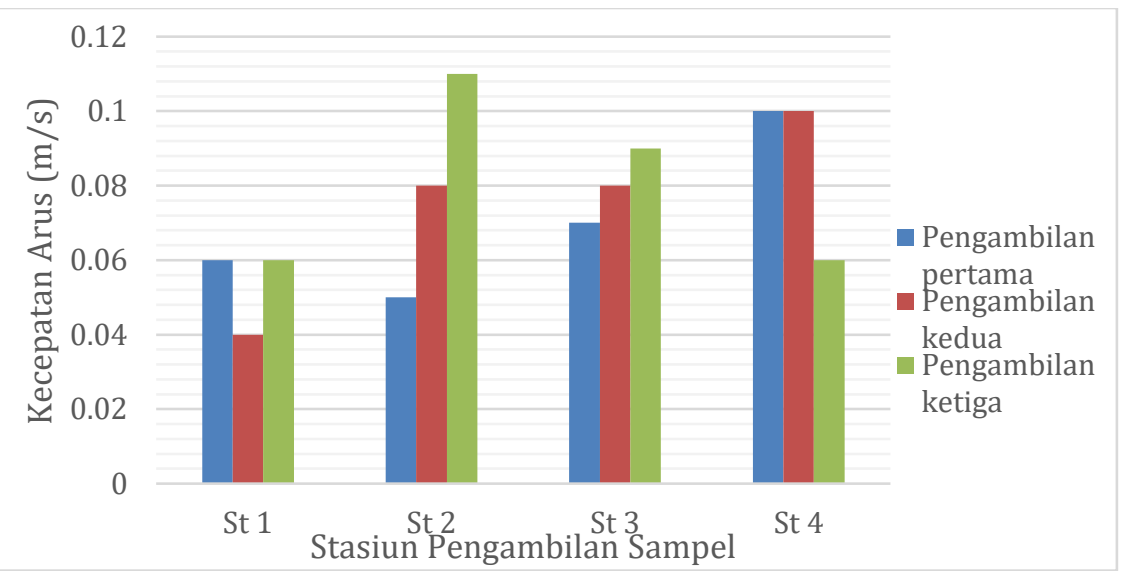

Gambar 4. Kecepatan arus di Perairan Pulau Tegal

Berdasarkan Gambar 4 diketahui bahwa kecepatan arus di perairan Pulau Tegal berkisar antara 0,04 $0,11 \mathrm{~m} / \mathrm{s}$ dengan rata-rata sebesar
$0,075 \mathrm{~m} / \mathrm{s}$. Kecepatan arus ini dianggap tidak cocok untuk kegiatan budidaya ikan kerapu bebek, hal ini sesuai dengan pendapat Departemen 
Kelautan dan Perikanan (2002) yang menyatakan bahwa kecepatan arus yang baik untuk pembesaran ikan kerapu bebek antara $20-50 \mathrm{~m} / \mathrm{s}$ (Tabel 1). Perubahan kecepatan arus ini berkaitan dengan massa air yang tidak selalu stabil ataupun pengaruh dari angin selama penelitian.

Derajat Keasaman (pH) Pulau Tegal

Nilai $\mathrm{pH}$ yang didapat di perairan Pulau Tegal sebesar 6. Nilai ini dianggap tidak baik untuk budidaya ikan kerapu bebek karena terlalu asam. Dimana $\mathrm{pH}$ yang baik untuk budidaya berkisar antara 6,5-9,0 (Kordi dan Ghuffron, 2004). Pengaruh dari $\mathrm{pH}$ ini juga dapat mempengaruhi tingkat kesuburan perairan karena berdampak pada kehidupan jasad renik, termasuk fitoplankton dan zooplankton.

\section{Nitrat Perairan Pulau Tegal}

Hasil pengukuran kandungan nitrat untuk lokasi budidaya ikan kerapu bebek di Pulau Tegal dapat dilihat pada Gambar 5.

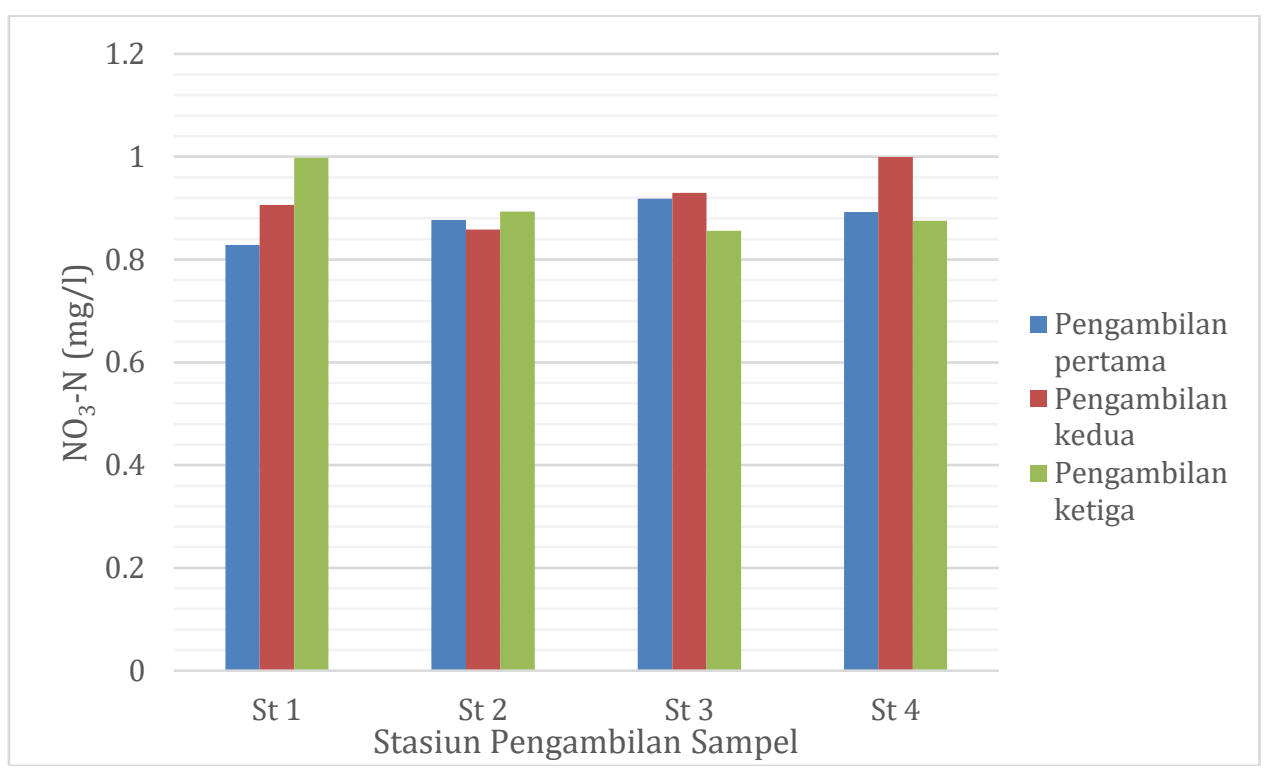

Gambar 5. Kandungan nitrat di Perairan Pulau Tegal

Berdasarkan Gambar 5 diketahui hasil nitrat berkisar 0,828 - 0,999 $\mathrm{mg} / \mathrm{l}$ dengan nilai rata-rata yang didapat adalah $0,902 \mathrm{mg} / \mathrm{l}$. Hal ini dapat dikatakan bahwa kandungan nitrat di perairan Pulau Tegal sangat baik untuk budidaya ikan kerapu bebek. Sesuai dengan pendapat Departemen Kelautan dan Perikanan (2002) yang menyatakan bahwa konsentrasi nitrat yang dibutuhkan untuk budidaya laut adalah berkisar antara $0,9-3,2 \mathrm{mg} / \mathrm{l}$.

\section{Fosfat Perairan Pulau Tegal}

Hasil pengukuran fosfat untuk lokasi budidaya ikan kerapu bebek di Pulau Tegal dapat dilihat pada Gambar 6. 


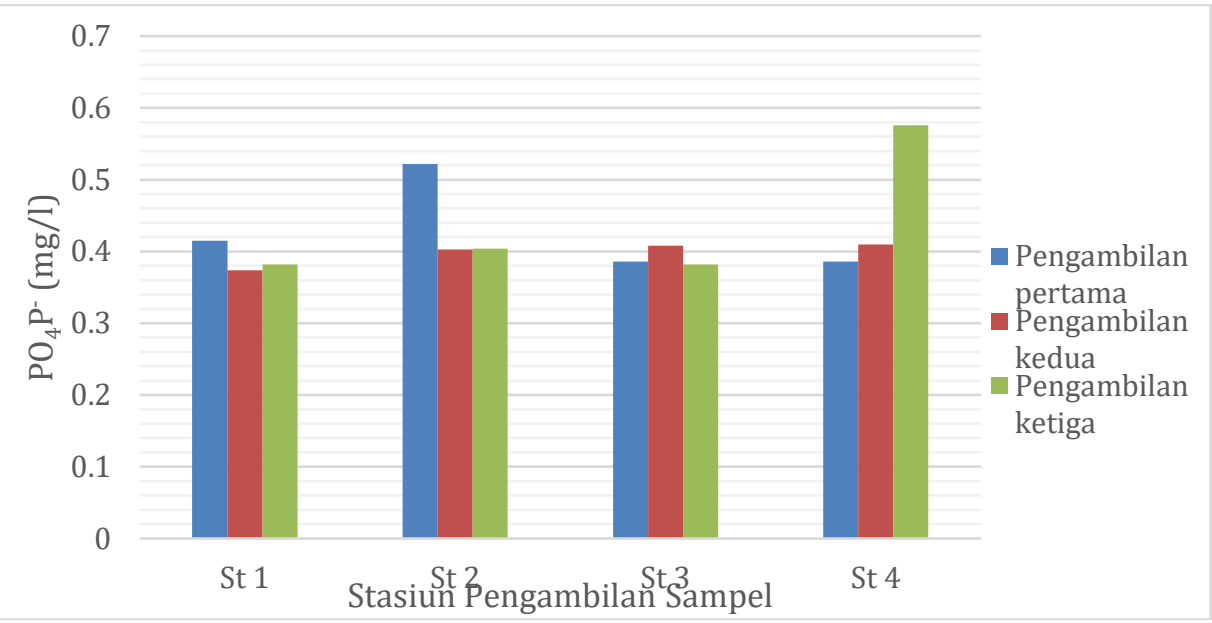

Gambar 6. Kandungan fosfat di Perairan Pulau Tegal

Berdasarkan Gambar 6 diketahui fosfat di perairan Pulau Tegal berkisar antara $0,374 \mathrm{mg} / \mathrm{l}-0,522 \mathrm{mg} / \mathrm{l}$ dengan nilai rata-rata $0,420 \mathrm{mg} / \mathrm{l}$. Nilai ini sesuai untuk budidaya ikan kerapu bebek karena menurut Wardoyo (2002), jika kandungan fosfat lebih dari $0,051 \mathrm{mg} / \mathrm{l}$ makan perairan bisa dikatakan baik. Baku mutu konsentrasi maksimum fosfat yang layak untuk kehidupan biota laut adalah $0,015 \mathrm{mg} / \mathrm{l}$ (KLH, 2004).

\section{Kesesuaian Perairan Pulau Tegal}

Setelah dilakukannya pengolahan data, pembobotan dan scoring berdasarkan sistem penilaian kesesuaian perairan untuk budidaya ikan kerapu bebek maka hasil skoring dapat diuraikan pada Tabel 3, 4, 5 dan 6.

Tabel 3. Kesesuaian perairan untuk budidaya kerapu bebek pada Stasiun

\begin{tabular}{ccccc}
1 & & & & \\
\hline Variabel & Rerata & $(\mathbf{A})$ & (B) & Skor \\
\hline $\begin{array}{c}\text { Kedalaman } \\
\text { Perairan }\end{array}$ & 19 & 5 & 3 & 15 \\
$\begin{array}{c}\text { Oksigen } \\
\text { Terlarut }\end{array}$ & 8,83 & 3 & 3 & 9 \\
$\begin{array}{c}\text { Kecerahan } \\
\text { Perairan }\end{array}$ & 12.67 & 1 & 3 & 3 \\
Salinitas & 32 & 5 & 3 & 15
\end{tabular}

\begin{tabular}{ccccc} 
Suhu & 30 & 5 & 2 & 10 \\
$\begin{array}{c}\text { Kecepatan } \\
\text { Arus }\end{array}$ & 0,05 & 1 & 2 & 2 \\
$\begin{array}{c}\text { Derajat } \\
\text { Keasaman }\end{array}$ & 6 & 3 & 2 & 6 \\
$\quad$ Nitrat & 0,910 & 5 & 1 & 5 \\
Fosfat & 0,390 & 5 & 1 & 5 \\
Skor total & & & & $\mathbf{7 0}$ \\
\hline $\begin{array}{c}\text { Nilai Skor } \\
(\%)\end{array}$ & & & & $\mathbf{7 0 \%}$ \\
\hline
\end{tabular}

Tabel 4. Kesesuaian perairan untuk budidaya kerapu bebek pada Stasiun

\begin{tabular}{|c|c|c|c|c|}
\hline Variabel & Rerata & (A) & (B) & Skor \\
\hline $\begin{array}{c}\text { Kedalaman } \\
\text { Perairan }\end{array}$ & 19 & 5 & 3 & 15 \\
\hline $\begin{array}{l}\text { Oksigen } \\
\text { Terlarut }\end{array}$ & 7,73 & 5 & 3 & 15 \\
\hline $\begin{array}{c}\text { Kecerahan } \\
\text { Perairan }\end{array}$ & 10,67 & 1 & 3 & 3 \\
\hline Salinitas & 32 & 5 & 3 & 15 \\
\hline Suhu & 30 & 5 & 2 & 10 \\
\hline $\begin{array}{c}\text { Kecepatan } \\
\text { Arus }\end{array}$ & 0,08 & 1 & 2 & 2 \\
\hline $\begin{array}{c}\text { Derajat } \\
\text { Keasaman }\end{array}$ & 6 & 3 & 2 & 6 \\
\hline Nitrat & 0,876 & 3 & 1 & 3 \\
\hline Fosfat & 0,443 & 5 & 1 & 5 \\
\hline Skor total & & & & 74 \\
\hline $\begin{array}{c}\text { Nilai Skor } \\
(\%)\end{array}$ & & & & $74 \%$ \\
\hline
\end{tabular}


Tabel 5. Kesesuaian perairan untuk budidaya kerapu bebek pada Stasiun

\begin{tabular}{|c|c|c|c|c|}
\hline Variabel & Rerata & (A) & (B) & Skor \\
\hline $\begin{array}{c}\text { Kedalaman } \\
\text { Perairan }\end{array}$ & 24,6 & 5 & 3 & 15 \\
\hline $\begin{array}{l}\text { Oksigen } \\
\text { Terlarut }\end{array}$ & 7,37 & 5 & 3 & 15 \\
\hline $\begin{array}{c}\text { Kecerahan } \\
\text { Perairan }\end{array}$ & 7,67 & 1 & 3 & 3 \\
\hline Salinitas & 32 & 5 & 3 & 15 \\
\hline Suhu & 30 & 5 & 2 & 10 \\
\hline $\begin{array}{c}\text { Kecepatan } \\
\text { Arus }\end{array}$ & 0,08 & 1 & 2 & 2 \\
\hline $\begin{array}{c}\text { Derajat } \\
\text { Keasaman }\end{array}$ & 6 & 3 & 2 & 6 \\
\hline Nitrat & 0,901 & 5 & 1 & 5 \\
\hline Fosfat & 0,392 & 5 & 1 & 5 \\
\hline Skor total & & & & 76 \\
\hline $\begin{array}{c}\text { Nilai Skor } \\
(\%)\end{array}$ & & & & $76 \%$ \\
\hline
\end{tabular}

Tabel 6. Kesesuaian perairan untuk budidaya kerapu bebek pada Stasiun 4

\begin{tabular}{ccccc}
\hline Variabel & Rerata & (A) & (B) & Skor \\
\hline $\begin{array}{c}\text { Kedalaman } \\
\text { Perairan }\end{array}$ & 26 & 1 & 3 & 3 \\
$\begin{array}{c}\text { Oksigen } \\
\text { Terlarut }\end{array}$ & 7,83 & 5 & 3 & 15 \\
Kecerahan & 7,67 & 1 & 3 & 3 \\
Perairan & 32 & 5 & 3 & 15 \\
Salinitas & 30 & 5 & 2 & 10 \\
$\quad$ Suhu & 0,08 & 1 & 2 & 2 \\
Kecepatan & & & & \\
$\quad$ Arus & 6 & 3 & 2 & 6 \\
$\begin{array}{c}\text { Derajat } \\
\text { Keasaman }\end{array}$ & & & \\
Nitrat & 0,922 & 5 & 1 & 5 \\
Fosfat & 0,457 & 5 & 1 & 5 \\
\hline $\begin{array}{c}\text { Skor total } \\
\text { Nilai Skor }\end{array}$ & & & & $\mathbf{6 4}$ \\
$\quad(\%)$ & & & & $\mathbf{6 4 \%}$ \\
\hline
\end{tabular}

Dari Tabel 3, 4, 5 dan 6 diketahui nilai kesesuaian bagi budidaya ikan kerapu bebek pada Stasiun 1 sebesar $70 \%$, Stasiun 2 sebesar 74\%, Stasiun 3 sebesar $76 \%$, dan Stasiun 4 adalah sebesar 64\%. Berdasarkan hasil tersebut dapat dikatakan bahwa Stasiun 1 dan Stasiun 2 adalah sesuai marjinal, Stasiun 3 cukup sesuai, sedangkan untuk Stasiun 4 perairan Pulau Tegal tidak sesuai.

\section{Kesimpulan dan Saran}

Hasil penelitian menunjukan bahwa perairan Pulau Tegal memiliki tingkat kesesuaian perairan yang cukup sesuai (St 3), sesuai marginal (St 1 dan St 2) dan tidak sesuai (St 4) untuk budidaya ikan kerapu bebek (Cromileptes altivelis).

\section{Daftar Pustaka}

Aslianti, T., Slamet, B., dan Prasetyo, G.S. 2003. Aplikasi Budidaya Ikan Kerapu Bebek (Cromileptes altivelis) di Teluk Ekas Kabupaten Lombok Timur. Jakarta: Badan Riset Kelautan dan Perikanan.

Brotowidjoyo. 1995. Pengantar Perairan dan Budidaya Air. Yogyakarta : Liberty

Balai Budidaya Laut Lampung. 2001. Petunjuk Teknis Pembesaran Kerapu Macan dan Kerapu Tikus. Jakarta: Direktorat Jenderal Perikanan Budidaya, Departemen Kelautan dan Perikanan.

Departemen Kelautan dan Perikanan. 2002. Pedoman Umum Penataan Ruang Pesisir dan Pulau-Pulau Kecil. Jakarta: Departemen Kelautan dan Perikanan.

Evalawati, Meiyana, M., dan Aditya, T.W. 2001. Modul Pembesaran Kerapu Bebek (Cromileptes altivelis) di Keramba Jaring Apung. Lampung: Balai Besar Pengembangan Budidaya Laut Lampung, Direktorat Pengembangan Sumber Daya Kelautan dan Perikanan. 
Kementerian Lingkungan Hidup (KLH), 2004. Keputusan Menteri KLH No. 51/2004 tentang baku mutu air laut untuk Biota Laut. Jakarta: KLH.

Kordi, M. dan Ghufran, H.K. 2004. Penanggulangan hama dan penyakit ikan. Jakarta: Penerbit Rineka Cipta dan Bina Adiaksara..

Mudjito, $1997 . \quad$ Evaluasi Penginderaan Jauh untuk Studi Dasar Lingkungan Wilayah Kerja UNOCAL Indonesia company Kalimantan Timur. Jakarta: Bidang Litbangtek Eksplorasi, Pusat Penelitian dan Pengembangan Teknologi Minyak dan Gas Bumi, LEMIGAS.

Nontji, A. 2005. Laut Nusantara. Edisi revisi. Jakarta: Penerbit Djambatan.

Paruntu, C.P. 2015. Budidaya Ikan Kerapu (Epinephelus tauvina Forsskal, 1775) dan Ikan Beronang (Siganus canaliculatus Park, 1797) dalam Karamba Jaring Apung dengan Sistem Polikultur. E-Journal Budidaya Perairan, 3(1): 1-10.

Tiskiantoro, F. 2006. Analisis kesesuaian lokasi budi daya keramba jaring apung dengan aplikasi sistem informasi geografis di Pulau Karimunjawa dan Pulau Kemujan. Tesis. Semarang: Program Pascasarjana, Universitas Diponegoro.

Nybakken, J.W. 1992. Biologi Laut Suatu Pendekatan Ekologis. Diterjemahkan oleh Eidman, Koesoebiono, Bengen, D.G., Hutomo, M., dan Sukarjo, S. Jakarta: Gramedia. 